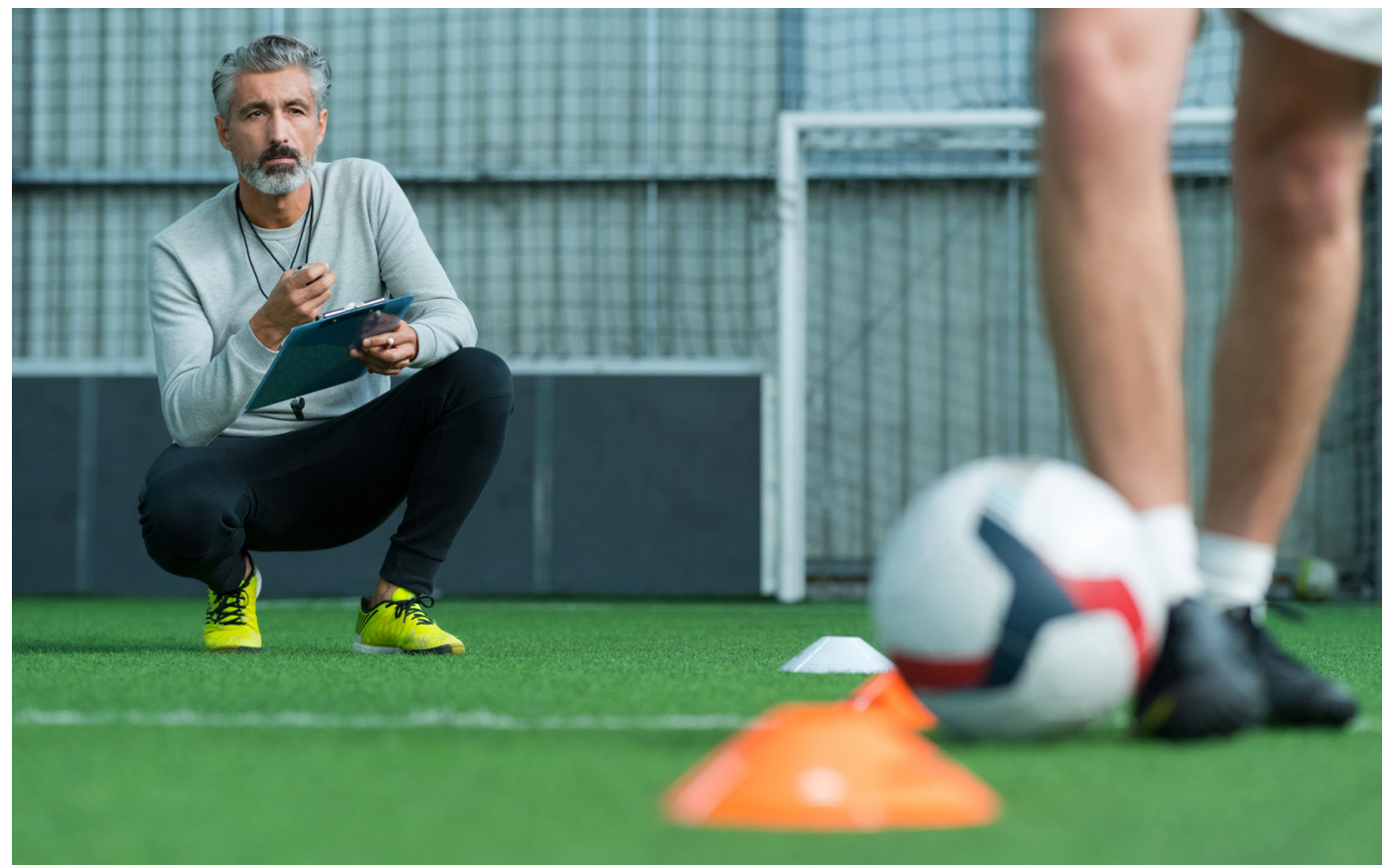

\title{
Træneren som gatekeeper, ressourcedistributør og partner for idrætstalenter
}

\section{Magt og etik i talentudviklingens relationer}

\author{
JENS CHRISTIAN NIELSEN, LOTTE STAUSGAARD SKRUBBELTRANG \\ \& JESPER STILLING OLESEN
}

Artiklen belyser relationer mellem unge talentfulde atleter og deres trænere. Ved at læse på tværs af interviewmateriale med unge idrætstalenter finder vi tre former for nøglerelationer trænere kan have i talentudviklingen, henholdsvis som gatekeepere, ressourcedistributører og partnere. Analyserne viser, at trænere indtager en nøgleposition i talentudvikling og talentudviklingsmiljøer, hvor de har en central betydning for tilblivelsen af unge talenter. Det diskuteres om den nøgleposition i talentudviklingen også indebærer et etisk ansvar for dem, der ikke kommer gennem gaten, får ressourcer distribueret eller opnår et partnerskab. 


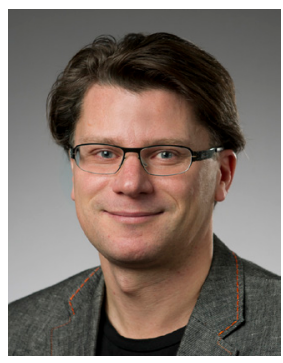

\section{JENS CHRISTIAN NIELSEN}

ph.d., lektor

DPU - Aarhus Universitet

jen@edu.au.dk

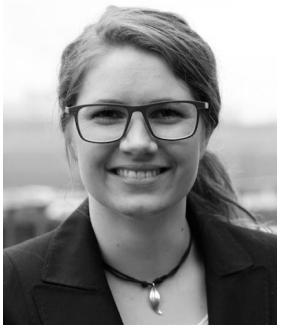

LOTTE STAUSGAARD SKRUBBELTRANG

ph.d., studielektor

Institut for Medicin og Sundhedsteknologi, Aalborg Universitet

lss@hst.aau.dk

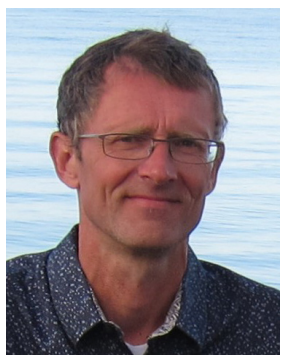

JESPER STILLING OLESEN

ph.d., lektor

DPU - Aarhus Universitet

jeo@edu.au.dk

Denne artikel belyser relationer mellem unge talentfulde atleter og deres trænere. Trænere indtager en nøgleposition i talentudvikling og talentudviklingsmiljøer, hvor de har en central betydning for tilblivelsen af unge talenter. Jowett og Wylleman (2006) peger på, at sportspsykologisk forskning har for stort fokus på enkeltaktører. De ser et behov for at tænke i flere retninger og bl.a. undersøge de påvirkninger, individerne udøver på hinanden. En relation har ikke bopæl i den enkelte, men er et produkt og en proces delt mellem to eller flere, påpeger de. Det er en pointe, som er i tråd med denne artikels forståelse af talent. Vi ønsker at undersøge betydningen af trænerrelationer i unges tilblivelsesprocesser som talenter ud fra den grundlæggende forståelse af, at talent ikke er et individuelt forhold, men et socialt og kulturelt fænomen (Nielsen et al. 2017, Skrubbeltrang et al. 2015, Karen \& Washington 2015). Tilblivelsen som talent sker ikke alene i kraft af idrætsudøverens individuelle evner, viljestyrke og commitment, men er en tilblivelse, der er dynamisk og sker sammen med og i relation til andre. Under inspiration af ny-materialismen (Mol \& Law 2004, Mialet 2006, Højgaard \& Søndergaard 2010, Fox \& 
Alldred 2017) undersøger vi talent som noget man gør, dvs. som noget der bliver gjort, udført eller opført. Vi er interesseret i det arbejde og de handlinger blandt aktører, der får talent til eller forhindrer det i at manifestere sig som en realitet. Talent er i denne forståelse ikke kun noget individet er eller har, men noget som gøres eller produceres af individet i samspil med en række aktører (Nielsen \& Olesen 2019). Når vi taler om tilblivelse af talent, svarer det ikke fuldstændigt til at tale om talentudvikling. Det er en social kategori, som nogen idrætsudøvere vælger og får mulighed for at tage på sig. Talentkategorien tilbyder en særlig mulighed for at blive til som ung og som idrætsudøver. Når vi taler om, at talent ligger i relationen, så er det fordi der både er nogen med særlige fysiske og mentale forudsætninger, der ønsker at tage kategorien på sig og identificere sig med dette talent, og der er nogen, der tildeler talentet til de udøvere, de mener har potentialet til at blive en del af senioreliten. Derfor indgår der også hele tiden en vurdering af, om atleterne fortsat har talent. Talentudviklerne har også mulighed for at inddrage talentet igen, hvis de skifter mening i deres vurdering af det biologiske humane materiale. På samme måde som køn og race er kategorier, der knytter sig til kroppen, knytter talent sig også til kroppen. Derfor er det ikke alle, der kan blive talenter. På den anden side, så er udøverne ikke uløseligt forbundne til talentkategorien. De kan bare lade være med at træne, så falder de helt automatisk ud af kategorien.

I artiklen har vi fokus på, hvordan idrætstalenter oplever betydningen af relationen til trænere for deres tilblivelse som talenter. Ved at læse på tværs af interviewmateriale med unge idrætstalenter finder vi tre former for nøglerelationer, trænere kan have i talentudviklingen, hhv. som gatekeepere, ressourcedistributører og partnere. Denne tredeling peger på forskellige analytiske dimensioner af relationen mellem trænere og talenter, som vel at mærke ikke er grundlæggende forskellige, men overlappende variationer af relationen. I vores analyser behandler vi, hvilken betydning disse forskellige former for relationer kan have for unge atleters tilblivelse som talenter i et livscyklusperspektiv, dvs. som en relation der både kan medvirke til, at talent skabes og opløses.

Artiklen er baseret på interviewmateriale med unge idrætstalenter fra et 4-årigt forskningsprojekt om den talentudvikling, der finder sted i idrætsklasser ${ }^{1}$ (Nielsen et al. 2017). Forskningsprojektet kombinerede kvantitative og kvalitative studier. I den kvalitative del foretog vi etnografiske casestudier, hvor vi fulgte fire idrætsklasser og 81 unge idrætstalenter fra 8. til 9. klassetrin (29 piger og 52 drenge). Vi har interviewet idrætseleverne op til tre gange i denne periode for at identificere foran-

1 Idrætsklasser er en dansk model for tidlig talentudvikling, hvor folkeskoler på 7.-9. klassetrin tilbyder særlige klasser for talentfulde atleter i alderen 12-16 år. Idrætseleverne selekteres til idrætsklasserne gennem en sportslig optagelsesproces. Idrætseleverne repræsenterer forskellige idrætsgrene. De seks største idrætsgrene i idrætsklasserne opgjort på antal atleter er fodbold, håndbold, svømning, ishockey, badminton og basketball. I alt udgør andelen af atleter inden for disse idrætsgrene 84 pct. De sidste 16 pct. repræsenterer mere end 30 forskellige idrætsgrene. 
dringer i deres deltagelse, relationer og engagement i elitesporten. Vi har bl.a. talt med idrætstalenterne om betydningen af deres relationer til trænere, og hvordan disse relationer har udviklet sig. Det er disse interview med idrætstalenter, der danner det primære empiriske grundlag for artiklens belysning af unge talentfulde atleters relationer til trænere i elitesportens talentudviklingsmiljøer. Vi trækker imidlertid også på observationer fra vores feltarbejde i relation til idrætsklasserne og interview med de trænere, der er tilknyttet idrætsklassernes talentprogram.

\section{VIDEN PÅ FELTET}

Allerede i 2004 påpegede Wylleman et al. (2004) i en artikel om atleters karrieretransitioner, at der i forskningen var et behov for at anvende et holistisk livstidsperspektiv på karrieren under og efter sport. Denne tilgang inkluderer transitioner, der sker undervejs i den atletiske karriere, såvel som de transitioner, der sker uden for det sportslige domæne. De refererer til Wylleman og Lavelles model for transition, hvor der er fokus på sportslige, individuelle, psykosociale og uddannelses- og beskæftigelsesmæssige overgange, og hvordan disse forskellige overgange influerer på hinanden. Ser vi nærmere på denne model, er et interessant aspekt, at trænere først for alvor får en vigtig psykosocial nøglerolle i ungdomstiden og den talentudvikling, der finder sted i denne periode. Forældre har stadig en vigtig rolle, men trænere bliver efterhånden de mest centrale nøglepersoner for atleters udvikling mod og overgange til senioreliten (Wylleman \& Lavelle 2004).

I nyere nordisk sportspsykologisk forskning er den holistiske tilgang også anvendt til at undersøge succesfulde atleters talentudviklingsmiljøer ( $\mathrm{fx}$ Henriksen 2010, Henriksen et al. 2010, Larsen et al. 2013, Stambulova et al. 2015). Denne forskning kommer i relation til trænere frem til, at deres rolle i succesfulde miljøer rækker væsentligt udover selve træningen af atleten. En nøglerolle for træneren er at etablere og opretholde miljøets kultur og hjælpe med at socialisere nye medlemmer ind i kulturen. I denne sammenhæng er Storm et al.'s (2014) undersøgelse af nøglepersoner i eliteatleters karriereveje særligt interessant. De knytter an til den holistiske og økologiske sportspsykologiske forsknings påpegning af trænerens relationelle nøglerolle i talentudviklingsmiljøer. Udgangspunktet for undersøgelsen er, at tilblivelsen af en eliteatlet er en social affære, hvor eliteatleter socialiseres ind i en specifik elitesportskultur. Trænere udpeges som de centrale nøglepersoner i talentudvikling, og to typer af relationer mellem trænere og talenter fremhæves som værende særligt betydningsfulde. Den ene type relation er en oftest kortvarig transitionsrelation, der vejleder og støtter atleten i vigtige overgange og passagepunkter mellem og til forskellige karriere- og udviklingsstadier. Den anden er en eksistentiel relation, der karakteriseres ved kontinuitet mellem forskellige karrierestadier ved at integrere sport og øvrigt liv og ved at have støttende indflydelse 
på processen i at blive en eliteatlet. ${ }^{2}$ Det er en relation, der skaber mening for atleten. En meningsskabelse der i flere tilfælde rækker ud over det sportslige domæne. Storm et al. henviser til, at Wylleman og Lavallee (2004) i deres model for atleters karriereforløb viser, at specifikke personer optræder som signifikante andre i specifikke stadier af atleters udvikling. Hvor særligt forældre, jævnaldrende og søskende har stor betydning i de indledende faser, har forældre og trænere størst betydning i talentudviklingens faser og trænere og partnere i faserne som senioreliteudøver. De påpeger, at talentudvikling ikke kun er et spørgsmål om at opbygge atletens ressourcer, forstået som kompetencer og livsfærdigheder, der gør dem i stand til at kunne overkomme krav om udvikling og overgange til nye karrieretrin. Det er også et spørgsmål om at opbygge miljøer med mange potentielt frugtbare relationer. Undersøgelsen peger på, at talentudvikling medfører konstruktioner af nye identiteter for atleterne, og at trænerne kan spille en vigtig rolle for atleternes måde at forholde sig til livet. Storm et al. ser derfor et potentiale i at skabe miljøer, der har blik for betydningen af dette.

I kraft af at Storm et al. (2014) har bedt deres respondenter om at fortælle, hvem der har været signifikante nøglepersoner i deres udvikling, giver deres undersøgelse oftest et positivt blik på relationerne mellem atleter og trænere. Deres fokus på, hvordan nøglepersoner forbinder sig positivt til atleters læring og udvikling i deres veje mod eliten, betyder imidlertid, at de sjældent har blik for, at trænere også har en magtfuld position, hvor de kan medvirke til, at atleters vej mod eliten ophører eller vanskeliggøres. Dette er imidlertid som påpeget af Kilger (2017) et generelt problem inden for idrætsforskning i talentudvikling. Hvor Storm et al. har set på eliteudøveres vej til eliten og betydningen af nøglepersoner retrospektivt, har vi har et andet blik, da vi primært ser prospektivt på tilblivelsesprocessen. Vi beskæftiger os derfor med udøvere, der på et tidspunkt er blevet udpeget som talenter, men som endnu ikke har nået senioreliten. Det vil sige, at de er midt i en tilblivelsesproces, som kan gå flere veje. Det medfører, at det ikke kun er succeshistorier om talenters relationer til trænere, vi får fortalt, men også fortællinger om udøvere, der oplever, at trænere er med til at slukke deres glød fremfor at tænde den. Denne tilgang finder støtte hos Jowett og Wylleman, der peger på et behov for at undersøge både, hvordan en relation initieres, hvordan den vedligeholdes og hvordan den ophører. Det de benævner livscyklussen af en relation i sport (Jowett \& Wylleman 2006). I denne artikel ser vi på trænerrelationens betydning for talenters tilblivelse i et sådant perspektiv. Trænere er i talentudviklingen i en magtfuld position, hvor deres relation til unge atleter har afgørende betydning for, om talent identificeres, selekteres og gives adgang til talentudviklingsmiljøer og -ressourcer, der gør en fortsat talenttilblivelse mulig.

2 De langsigtede relationer Storm et al. finder, hænger muligvis sammen med eller forstærkes af, at Danmark er et relativt lille land, hvor det er relativt få personer, som varetager talentudviklingen inden for de forskellige idrætsgrene - med delvis undtagelse af fodbold og håndbold. 


\section{ANALYSE AF TALENT-TRAENER-RELATIONER}

Analysen af unge idrætstalenters oplevelse af relationen til trænere er baseret på en tværgående læsning af vores interviewmateriale. I denne læsning har vi undersøgt, hvilke trænerrelationer de unge har, hvilken betydning relationerne tillægges og hvordan både relationer og betydninger kan ændre karakter. De unge idrætstalenter, vi analytisk bruger som eksempler på betydningen af, hvordan forskellige og nogle gange skiftende relationer til trænere har afgørende indflydelse på deres muligheder for at gøre talent, repræsenterer mere end deres unikke egen stemme. De viser på tværs af interviewene nogle af de forskellige betydninger, som relationen til trænere på godt og ondt kan have for udøvernes udvikling og muligheder for at gøre karriere inden for elitesport.

\section{TRAENERENS BETYDNING FOR TILBLIVELSEN AF SYNLIGE TALENTER}

Betydningen af relationen til trænere træder tydeligt frem, når vi ser på de unge i vores undersøgelsesmateriale, der fremstår som synlige talenter med masser af tegn på deres talent, $\mathrm{fx}$ at de er udtaget til landsholdssamlinger. Her forekommer trænere at have medvirket kraftigt til at skabe og opretholde disse unges talentfuldhed og evne til at manifestere deres talent med succes. Det følgende eksempel viser tydeligt, at træner-atlet-relationen ikke kun handler om meningsskabelse, men at gatekeeping og distribution af muligheder udgør en central del af udvekslingen mellem atlet og træner. Vi får gennem eksemplet indblik i, hvordan trænere kan virke som gatekeepere, distributører af ressourcer og sparringspartnere for et ung talent.

Ishockeyspilleren Niklas har i en alder af 17 år vist sig at kunne begå sig på senioreliteniveau i dansk ishockey og skal nu til udlandet og spille i den canadiske juniorliga for at videreudvikle sit talent. Niklas fortæller i interviewene med os, at hans trænere har haft stor betydning for hans talentudvikling. Af særlig betydning for hans udvikling peger han på, at han som 16-årig fik mulighed for at få debut på senioreliteholdet: "Det betød at jeg og alle andre for alvor begyndte at se mig som et talent" (Niklas - interview 2). På dette tidspunkt var der trænere i hans klub, som anså ham som et stort talent. Trænerne indtog en rolle som gatekeepere og tilbød ham adgang til at deltage i dele af seniorholdets træning og mulighed for spilletid på senioreliteholdet i den bedste danske ishockeyliga, Superisligaen. Muligheder og særlige vilkår som det ikke er alle forundt. Nogen vælges på bekostning af andre (jf. Epstein 2014).

Niklas oplever således, at der er trænere, som har åbnet døre for ham og gjort hans tilblivelsesproces som talent mulig. Niklas peger på, at det har stor betydning for ham, at trænerne viser ham tillid og tror på hans talent. Han er dog bevidst om 
og får eksplicit at vide af trænerne, at han på dette tidspunkt i sin udvikling er med for at lære og for at få erfaringer, der kan bidrage til at udvikle ham som spiller. I hans første sæson er det derfor begrænset, hvor meget spilletid han får i kampene på seniorholdet, da trænerne vil beskytte ham og afstemme forventningerne til hans præstationer til det aktuelle udviklingsniveau.

Tilliden fra trænerne ser Niklas som en betydningsfuld årsag til den udvikling, han gennemgår i sin anden sæson på seniorplan. Niklas træner og spiller i denne sæson udelukkende med seniortruppen og han får sit gennembrud i Superisligaen, hvor han scorer nogle vigtige mål for holdet. Han bliver efterfølgende valgt til årets unge spiller i ligaen. Selvom der ikke hersker tvivl om, at Niklas arbejder hårdt på at blive en dygtig ishockeyspiller og indfri det potentiale, han og andre oplever, er til stede hos ham, er det også tydeligt for Niklas, at det at få masser af spilletid i den bedste kæde med andre dygtige spillere, er det, som gør det muligt for ham at fremvise sit talent og udvikle det yderligere:

En af de store ting for min udvikling er, at jeg fik lov at spille $i$ kæde med de to topscorere på holdet. Det har selvfølgelig gjort en kæmpe betydning at jeg fik lov til det. (Niklas - interview 2)

Mialet har i sin forskning i tilblivelsen af videnskabelige genier vist, at geniale forskere i praksis støttes af omfattende netværk, der på en gang udvider deres kompetencer, gør dem i stand til at opfinde og blive anerkendt for deres ekstraordinære

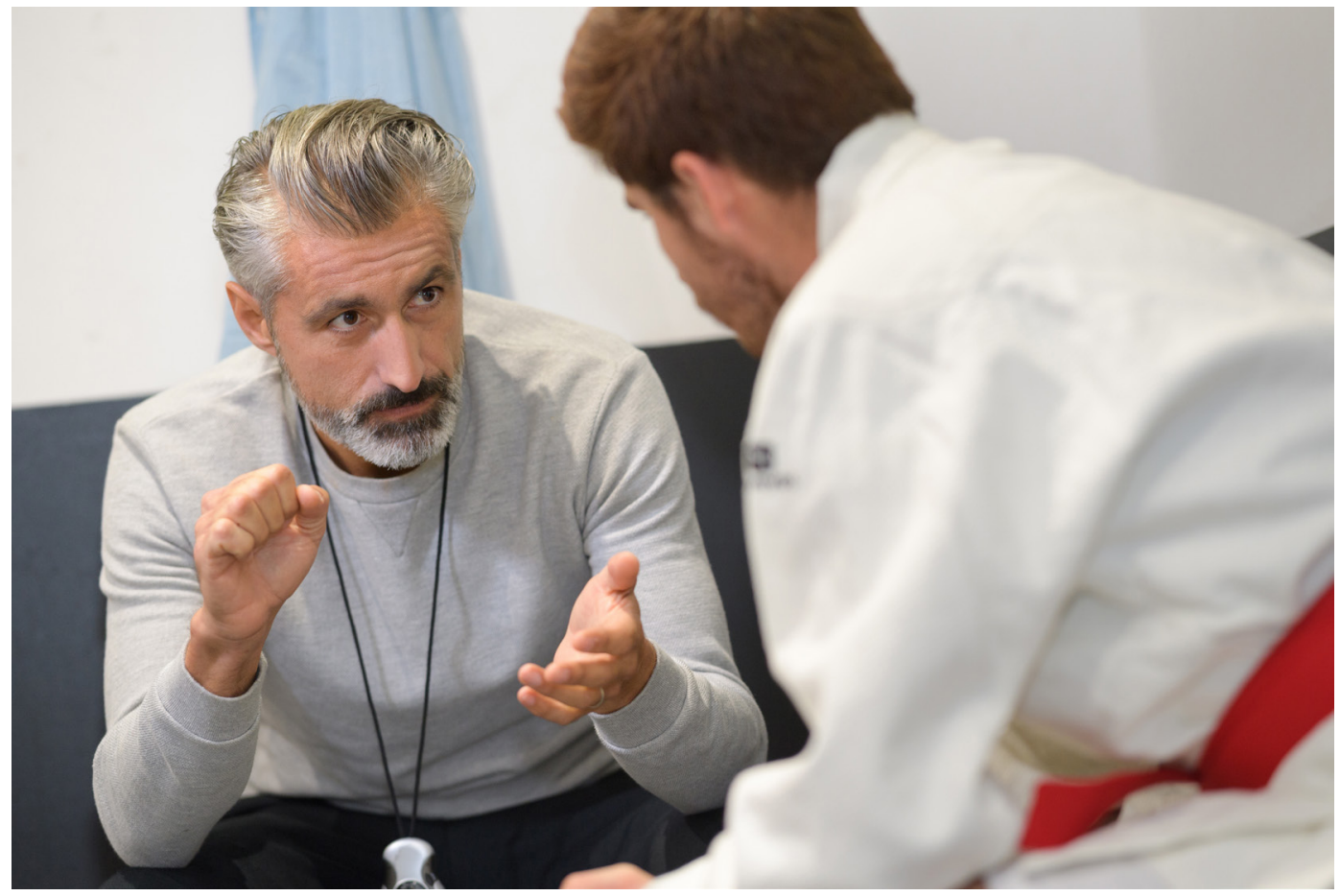


videnskabelige evner (Mialet 2006, 2009). Med inspiration fra denne kan vi tale om, at der finder en distribuering af ressourcer og muligheder sted, der gør det muligt for Niklas at indtage positionen som talentfuld. Det handler således ikke kun om, at trænerne giver Niklas adgang til eliteholdet og muligheden for på lige fod med andre at tilkæmpe sig en fast plads på eliteholdet, men også om at han får tildelt særlige muligheder for at udfolde sit potentiale. Dette sker for det første ved, at han bliver sat i kæde sammen med de dygtigste og mest rutinerede spillere. En distribuering af ressourcer og muligheder, som ikke tilbydes alle unge spillere. For det andet tildeles Niklas samtidigt en position, hvor han ikke måles på samme kriterier som de etablerede seniorelitespillere, men som en spiller i udvikling, et synligt talent, hvorved forventningspresset til at fremvise præstationer på højeste niveau kan reduceres.

Niklas er således en spiller, som trænere finder det værd at tildele ressourcer og investere i. Det kommer også til udtryk ved, at trænerne taler med ham om hans udvikling, og de forventninger de har til ham, men også hvad de kan gøre for at støtte ham og sørger for, at der ikke kommer et negativt forventningspres på ham. Dette aspekt er vigtigt at have med i relation til distribueringen af ressourcer. Udviklingen af talenter ses ofte som en investering, der gerne skal give et udbytte i kraft af, at spillerne når senioreliten. Niklas har blik for, at trænere også har en interesse i, at de talenter, der distribueres ressourcer til, bliver succesfulde. Trænere skal ligeledes kunne fremvise beviser på, at de er dygtige talentudviklere. Det kommer frem, da vi spørger Niklas til, hvorvidt klubben og træneren er ærgerlige over at miste ham i den kommende sæson:

Jeg tror, at det har en stor betydning, at klubben fär sendt en spiller videre. Det kan fä nye spillere til klubben. Det er også godt for træneren. Han var min forste træner som seniorhockeyspiller. Så man kan sige, at jeg er en af hans spillere, fordi at det var mit første år på seniorniveau, at jeg havde ham og han tog mig på ligaholdet. På hans $C V$, der er det også godt at have stående, at han har fået mig videre. (Niklas - interview 2)

I talentudviklingen kan der således blive skabt en form for alliance og tæt partnerskab mellem talenter og trænere, hvor begge parter har stor interesse $\mathrm{i}$, at talentets tilblivelse og stræben mod senioreliten lykkes. Værd at bemærke er det sjældent sådan, at partnerskabet mellem talent og trænere udelukkende ses som investering af ressourcer, da trænere og de synlige talenter får opbygget en tæt social relation. Niklas kan da også fortælle, at han bruger træneren som en vigtig samtalepartner og er sikker på, at han vil bevare kontakten til ham, mens han er i Canada.

Når vi ser på synlige talenter som Niklas, fremtræder det tydeligt, at trænere både optræder som gatekeepere, der kan åbne døre og skaber kontakt til talentud- 
viklingsmiljø, som ressourcedistributører, der tildeler ressourcer, der muliggør og understøtter talentets fortsatte tilblivelse, og som partnere, der selv kan have noget på spil emotionelt, socialt og karrieremæssigt i forhold til tilblivelsen af talentet.

Vi vil i det følgende behandle, hvordan relationen mellem trænere og talenter udspiller sig i vores materiale - også hvis talentet forekommer mindre indlysende.

\section{TRANERENS BETYDNING FOR SELEKTION AF MINDRE SYNLIGE TALENTER}

Trænere har en betydningsfuld rolle for, hvem der optages i et talentprogram, $\mathrm{fx}$ gennem optagelsesprøver, hvor de vurderer, om ansøgere har det fornødne potentiale til at blive optaget (jf. Kilger \& Jonsson 2015, Krogh Christensen 2009). Derfor er der behov for at afsøge, hvilke selektionskriterier trænere anlægger, og hvorvidt de er legitime (Ronglan 2015). Vi har i vores empiriske undersøgelsesmateriale flere eksempler på, at der er unge, som ikke optages i en idrætsklasse, fordi de vurderes ikke at være dygtige nok inden for deres idrætsgren. Det gælder både, hvis ansøgeren ikke har de fornødne tekniske kompetencer og færdigheder, eller hvis de ikke vurderes at have den rette indstilling til at indgå i et talentudviklingsmiljø. Det anses ofte som særligt problematisk, hvis ansøgere ikke vurderes at have commitment til elitesport, da det af gatekeeperne til idrætsklassen ofte ses som en forudsætning for at indgå i talentudviklingsmiljøet. Modsat finder vi, at sportslige færdigheder i højere grad opfattes som noget, der kan tillæres undervejs i forløbet, fx udpeges det som særligt problematisk, hvis atleter "ikke har den rette mentalitet", mens det at have "indstilling og arbejde som en terrier" kan kompensere for manglende teknik. Denne tendens til at gøre det til et iboende træk ved eleven, hvorvidt de har den rette indstilling til at ville udvikle sit talent og indgå i et talentudviklingsmiljø, står i modsætning til en britisk undersøgelse af talentudvikling (Martindale et al. 2007), hvor commitment anses som noget, der kan udvikles hos idrætsudøvere. Hvis det er rigtigt, stiller det spørgsmålstegn ved legitimiteten i et af de centrale selektionskriterier, gatekeeperne til idrætsklassens talentprogram anvender. Russell et al. (2013) peger på en tilsvarende problematik, når de vurderer, at den tidlige talentudvælgelse ofte er baseret på modenhed, kropsmål og sociale forudsætninger snarere end talent.

Et interessant eksempel på, at trænere - sammen med klub og skole - har en magtposition som gatekeepere, der gør dem i stand til at holde nogen unge ude, er da en ung ansøger kun tilbydes en betinget adgang til idrætsklassens talentudvikling, selvom han vurderes som værende en dygtig fodboldspiller sportsligt set. Men da trænerne i forvejen har kendskab til den unge, som indgår i et socialt miljø med andre unge, der karakterises som "de forkerte mennesker", lever usundt i kraft af, at han ryger og er ustabil i sit fremmøde til træning i fodboldklubben, stilles der 
spørgsmålstegn ved, om han kan indgå i et eliteorienteret talentudviklingsmiljø. I dette tilfælde tilbydes den unge ikke optagelse i idrætsklassen, men får en prøveperiode, hvor han kan få lov at deltage i talentprogrammets morgentræning og træningsmiljøets aktører kan se ham an og vurdere, om han er i stand til at vise det fornødne commitment til elitesport. Den gatekeeping, trænerne foretager i dette tilfælde, betyder ikke, at de smækker døren helt i, men at de holder opsyn og kan administrere en betinget adgang til deltagelse i en del af talentprogrammet.

Omvendt kan kendskab til spillerne også medvirke positivt til, hvorvidt der bliver givet adgang til idrætsklassen eller ej. En anden ung spiller har til optagelsesprøven haft problemer med tempoet. Talentchefen i klubben er på baggrund af optagelsesprøven i tvivl, om de skal give adgang til idrætsklassen. Imidlertid kan U12-træneren, der til dagligt er træner for spilleren, fortælle, at han normalt træner godt og har en træningsparathed, der tyder på, at han har den rette indstilling. Trænerne vælger derfor at optage ham i idrætsklassen. Disse to eksempler viser, at trænerne for det første er i en magtposition, hvor de både kan give og forhindre adgang til talentudviklingsmiljø. For det andet, at de i deres vurderinger af, hvem der skal have adgang, anlægger kriterier, der rækker ud over specifikke sportslige vurderinger af selve præstationen til optagelsesprøverne og inddrager deres bredere kendskab til ansøgerne. I den forstand kan selv en holistisk tilgang til talentudvikling både være inkluderende og ekskluderende. Træneren er en nøgleperson i selektionen af, hvem der anses for at have det fornødne talent, der berettiger til en plads i et talentudviklingsmiljø. Men retten til at fordele pladserne medfører også, at de har en position, hvor de medvirker til at sortere og fratage andre håbefulde atleter adgangen til bestemte mulighedsstrukturer. I de to givne eksempler har vurderingen af deltagernes sociale forudsætninger en afgørende betydning for hvordan og på hvilke præmisser, der gives adgang til talentprogrammet, hvilket også kan identificeres som en problematik i talentudvælgelse generelt (Russel et al. 2013).

\section{DISTRIBUERING AF RESSOURCER I TALENTUDVIKLING}

I elitesporten er der generelt fastlagte normer for distribuering af ressourcer, fx et bestemt antal pladser på holdet, hvor det er op til atleterne at tilpasse sig talentkategoriens umiddelbare objektive normer om at kunne klare udtagelseskrav i en given aldersgruppering. Med mindre det fremstår tydeligt for alle, at man er et talent med stort potentiale, som det fx var tilfældet med ishockeyspilleren Niklas, så kan det at stå overfor sådanne krav og normer skabe tvivl hos atleter, om de er gode nok, og om det er værd at satse på en elitekarriere. Baseret på vores undersøgelsesmateriale kan vi se, at det er en problemstilling en del unge atleter oplever at stå overfor. 
Henrik er et eksempel på en atlet, der er placeret i et sådant dilemma. Henrik er en god fodboldspiller, spiller i en eliteklub og går i 9. klasse på en idrætsskole. Han er lige rykket op fra U15 til U17. På U15 var han fast mand på førsteholdet, men han har ikke formået at få en fast plads på U17-førsteholdet. Til træning kan han godt mærke, at der er hård kamp om pladserne på førsteholdet med den årgang, der er et år ældre. Henriks dilemma opstår, fordi han står overfor at skulle vælge ungdomsuddannelse, og han er i den situation, at han bor i en anden by end elitefodboldklubben og den idrætsskole, han har gået på de seneste tre år. Henrik er derfor i tvivl, om han tør tro på, at han får en plads på førsteholdet og vælge et gymnasium i samme by, eller om han skal vælge gymnasiet i den by, han bor i og skifte til den lokale klub, der ikke spiller på samme eliteniveau. Henrik oplever, at det er en yderst vanskelig beslutning, han står overfor.

Det er jo noget, man lever og ånder for, det er jo fodbold og så lige pludselig skal bestemme, om man vil spille det på det højeste plan i Danmark eller det næsthøjeste. Det er en stor beslutning at skulle tage. (Henrik - interview 2)

Henrik er bevidst om, at det har betydning for hans udvikling som fodboldspiller, hvorvidt han spiller sammen med andre, der er på et højt niveau, og at det vil vanskeliggøre hans udvikling at skifte væk fra eliteklubben. Henrik oplever, at det er et dilemma, han selv skal håndtere, og ikke en beslutning, han får rådgivning af trænerne til at træffe. Han fortæller, at hvis han vidste, at han havde gode chancer for at etablere sig på førsteholdet, og han fik at vide, at trænerne troede på ham, ville han formentligt vælge at satse på at blive. Henrik efterspørger commitment fra trænernes side. Imidlertid betyder den manglende tilkendegivelse fra trænerne, at han hælder mod at vælge det lokale gymnasium og dermed også skifte klub. Henrik frygter at stå i en situation, hvor han ikke kan spille sig på førsteholdet og vil have lang transporttid til sin uddannelse med de sociale komplikationer, det kan give.

Når det at være på førsteholdet eller det at kunne klare udtagelseskrav betyder meget for ens plads i talentkategorien, forekommer det logisk, at der er atleter, der mister anerkendelse og kommer under pres for at vedblive med at bevare deres position i talentkategorien, hvis de er skadede. Et eksempel er fodboldspilleren Mikkel, der fortæller om en træner, der ikke giver ham nogen form for opmærksomhed, da han er skadet. Mikkel mister som følge af skaden ikke bare status som fodboldspiller og sin plads i det sociale fællesskab i fodboldklubben. Det får også betydning for hverdagen i den idrætsklasse, han går i, da det sociale fællesskab og den enkeltes status i klassen er knyttet til den sportslige deltagelse og position. Mikkel oplever et identitetstab som følge af skaden. I interviewmaterialet er der flere eksempler på, at skadede atleter oplever, at de mister værdi, og at relationerne til både trænere og holdkammerater svækkes. Skader fremstår for de unge som 
potentielt farlige for deres karriere og betydningsfulde for deres engagement $\mathrm{i}$ og relation til det talentudviklingsmiljø, de er en del af (Nielsen et al. 2017).

Imidlertid er der atleter, som făr distribueret masser af muligheder, $\mathrm{fx}$ for at spille opad og gøre sig erfaringer med overgange inden andre atleter. Det gælder først og fremmest de atleter, som opfattes som særligt talentfulde, og som det i klubber og af trænere ses som nødvendigt at etablere særlige tiltag for, så man sikrer deres fortsatte status som talent. Vi har i vores undersøgelsesmateriale en del eksempler på atleter, som får særlig støtte, fx får de særlige aftaler omkring fritagelse fra skole og lektier. Vi har endda også eksempler på atleter som under skadesforløb får særlig støtte og opmærksomhed, herunder adgang til eliteholdenes sundhedseksperter. Ligesom nogle af de unge fodboldspillere, der tidligt får en kontrakt, oplever, at det også betyder, at trænerne efterfølgende viser en anden interesse for dem, og de fx ikke i samme grad som de øvrige skal tilkæmpe sig fast spilletid. Hovedreglen er, at de atleter, der făr tilbudt og distribueret særlige muligheder og mere skræddersyet former for talentudvikling, anses som åbenlyst værd at satse på. Det er særligt blandt denne gruppe af atleter, at relationen til trænere og klub begynder at have karakter af et partnerskab, der også rummer aktørskab for den unge. Det forekommer vanskeligere for og optræder derfor sjældnere blandt de mange unge, der kæmper med deres tilblivelse som talent, hvilket efterlader os med spørgsmålet, om elitesporten tilsigtet eller utilsigtet forskelsbehandler på en etisk uforsvarlig vis (Bailey \& Toms 2011, Hardman et al. 2010). Elitesporten og dens trænere har også et ansvar for, hvordan den behandler og efterlader unge, der har identificeret sig med det talent, de er blevet tilbudt, men hvor man ikke længere gengælder deres engagement.

\section{TRANERRELATIONER KAN BÅDE STYRKE OG SVAKKE UNGE TALENTERS COMMITMENT TIL ELITESPORT}

Trænere har en nøgleposition i fordelingen af muligheder og ressourcer i talentudviklingen. Derfor forekommer det logisk, at deres relation til unge atleter er af stor betydning for de unge atleters commitment. Storm et al. (2014) peger på, at trænere ofte er nøglepersoner, der både kan støtte og vejlede unge atleter i vigtige overgange og med at skabe mening i tilblivelsen som eliteatlet. Det er tydeligt i vores undersøgelse, at trænere kan indtage sådanne nøglepositioner, fx fortæller basketballspilleren Oliver om vigtigheden af, at både klubtræner og landstræner fortæller ham, at han er en af de spillere, de anser som havende størst potentiale og regner med i landsholdssammenhæng. Det giver selvtillid og tro på egne evner.

Trænere har således en vigtig rolle i at hjælpe atleterne med at fastholde deres engagement. Fx fortæller svømmeren Mark, at hans træner hjælper ham med at fastholde sit engagement i en periode, hvor han kæmper med at finde lysten til 
elitesvømningen. Træneren har både gjort det klart for Mark, hvor vigtig han er for fællesskabet på holdet, og han har formået at få Mark til at genfinde motivation og mening med svømningen ved at forholde sig til, hvem Mark er og gerne vil være som person: "Jeg har af min træner fået fede billeder på, hvem jeg egentligt er som person, og hvad jeg brænder for" (Mark - interview 2).

Vi har i vores interview med unge atleter flere eksempler på, at trænere kan være med til at skabe mening og give identitet til udøvere. Storm et al. (2014) kalder denne relation for en eksistentiel relation. Det er en type relation, der fremhæves af de unge atleter som værende af stor betydning for at fastholde deres engagement i tilblivelsen som talent. På samme vis som atleterne skal kunne fremvise commitment, er det vigtigt for vores unge atleter, at der er trænere, som investerer deres engagement i dem.

Imidlertid er det ikke givet, at atleterne oplever, at der er trænere, som har brændende engagement i dem, og at trænerne indvirker positivt på tilblivelsesprocessen som talent. Svømmeren 15-årige David har valgt at ophøre med elitesport, når svømmesæsonen er overstået. Han har tidligere haft en træner, der støttede ham og var med til at gøre den store træningsindsats i svømning meningsfuld. Nu har han fået ny træner, han oplever som autoritær. David oplever, at træningen er blevet en sur pligt. Bl.a. forlanger træneren, at hvis svømmerne har været syge, skal de efterfølgende træne ekstra for at indhente det forsømte. Dråben for David er, at træneren stiller spørgsmålstegn ved hans seriøsitet, fordi han en dag om ugen dyrker fodbold. Træneren vil have, at David skal fravælge fodbolden, hvilket David

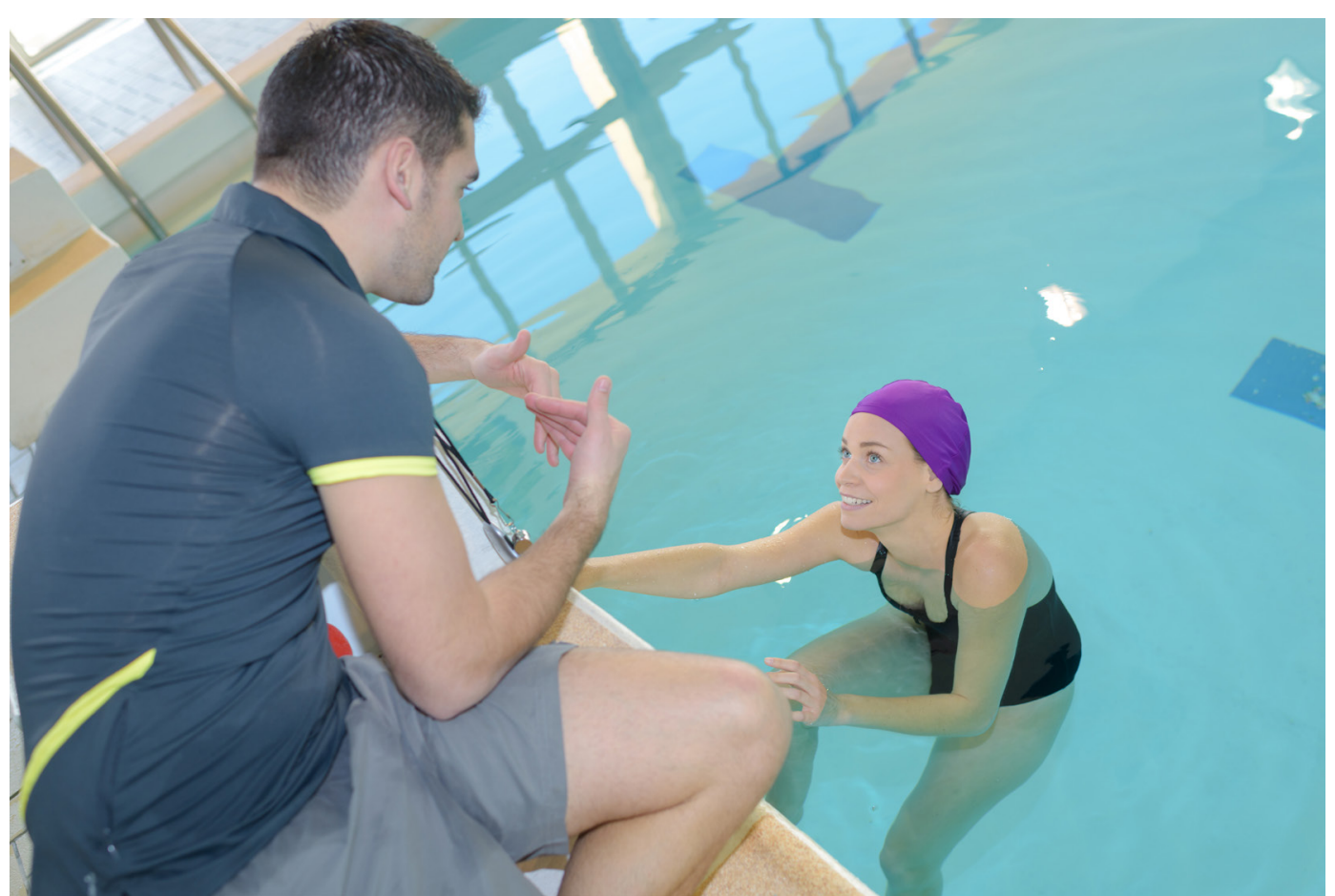


ikke ønsker. David făr efterfølgende ikke lov til at deltage i en holdkap, selvom han ud fra sine tider er blandt de bedste og berettiget til at deltage. Vi kan med Karen og Washington (2015) tale om, at David oplever en manglende access fairness fra træneren side. For David betyder det, at hans engagement til elitesporten er ved at opløses og ambitionerne forsvinder, hvilket han først og fremmest tillægger relationen til træneren. David er ikke den eneste atlet, der oplever, at deres trænere ikke har blik for dem som forskellige individer. Vi har i undersøgelsen endda talentfulde atleter på højeste niveau inden for en holdsport, der oplever, at ungdomslandsholdstræneren skaber et træningsmiljø, der er så seriøst og konkurrencepræget, at de mister lysten til fortsat at engagere sig i eliteidrætten og ophører med at spille på landsholdet. Relationer til trænere kan have en ganske afgørende betydning for, hvorvidt de unge atleter kan skabe en mening med og se mulighederne i at blive til gennem talentkategorien. For nogle unge atleter ender det med, at de ikke længere kan se en fremtid inden for elitesporten.

Både Becker (2009) og Storm et al. (2014) fremhæver betydningen af, at trænere viser en ægte interesse i atleter som individer, og at relationen rækker ud over sportens domæne. Det fremhæves ligeledes af de unge atleter i vores undersøgelse, der ofte betoner vigtigheden af trænere, der interesser sig for, hvordan de trives på og uden for banen. Mange af vores informanter fortæller faktisk også, at de møder en udbredt interesse for deres skoleliv og fremtid blandt trænerne. ${ }^{3}$ Et eksempel er svømmeren Astrid. Hun har de seneste par år haft en træner, der er vigtig for hende, fordi han kan tale med hende om problemer uden for svømmehallen, der berører og påvirker hende. Fx har hun gjort brug af træneren som samtalepartner i relation til hendes forældres skilsmisse, hvor hun havde svært ved at koncentrere sig om svømningen. Det har haft stor betydning for hendes trivsel. Samtidigt har træneren været dygtig til at hjælpe hende med at fokusere på de positive ting ved svømningen uanset resultatet. Astrid har tidligere oplevet, at hun kunne blive i dårligt humør, når hun ikke præsterede på det niveau, hun selv havde forventet. Andre atleter peger tilsvarende på, at det er vigtigt, at trænere interesserer sig for deres samlede liv, da det har stor betydning for deres deltagelse i elitesporten. Omvendt kan det være demotiverende for de unges engagement, hvis trænerne kun ser dem gennem talentkategorien.

3 Et forhold, der sandsynligvis forstærkes af, at atleterne går i idrætsklasser, hvor der er en relativ tæt kobling mellem deres sportsudøvelse og skolegang (Nielsen et al. 2017). 


\section{TRANERE HAR ANSVAR FOR AT TALENT KAN BLIVE TIL PÅ FORSVARLIG VIS}

Når vi ser på vores unge atleter, er det tydeligt, at trænerne spiller en betydelig rolle i deres tilblivelse som talenter. Selvom vi er i de tidlige faser af talentudviklingen, har de fleste unge atleter allerede gjort sig erfaringer med forskellige trænerrelationer. Relationer der på forskellige måder har betydning for deres engagement $\mathrm{i}$ elitesporten, og i nogle tilfælde også for at dette engagement svækkes eller ligefrem ophører.

Vi har tidligere hørt om Niklas, der på mange måder viser, hvor vellykket tilblivelsen som talent kan ske i interaktion med trænere, der ser hans potentiale, og tilbyder ham særligt tilpassede muligheder for at udvikle sig. Afslutningsvist vil vi med Sandra give et eksempel på en talenttilblivelse, der ligeledes peger på betydningen af trænerrelationer for talentets tilblivelse, men også indikerer, at de samme relationer kunne have medvirket til at talenttilblivelsen ophørte.

Sandra er en dygtig håndboldspiller. Da vi interviewer hende første gang, spiller hun på eliteklubbens U14-hold og er også i U16-truppen. Under vores interview med hende fortæller hun, at det ikke altid har været sådan. Som U12-spiller syntes hun ikke, at hun var særlig god. Men som U14-spiller fik hun en træner, der havde tiltro til hende og motiverede hende til at udvikle sit spil. Træneren udtog hende til førsteholdet, selvom hun ikke havde troet, at det var muligt for hende. Det har været meget betydningsfuldt for hendes commitment til elitesporten. Sandra peger på, at den trænerrelation og det træningsmiljø, hun fik adgang til, har været med til at dygtiggøre hende som spiller, $\mathrm{fx}$ arbejdede træneren individuelt med hende som spiller og gav hende dermed adgang til teknisk træning på et højt kvalificeret niveau. I det andet interview med Sandra peger hun på trænerens store betydning, når hun skal se tilbage på sin tilblivelse som talent:

Han betød meget for mig. Vigtigt at blive set og at træneren lægger mærke til en. Vigtigt at få at vide, hvis man gør det godt-eller hvis der er ting som kan forbedres. (Sandra - interview 2)

Dialogen med træneren er vigtig for at få at vide, hvordan man udvikler sig, og hvor man kan forbedre sig. Sandra fremhæver, at træneren både var god til at rose hende, men også minde hende om at være ydmyg, særligt når hun spillede med de ældre spillere. Trænere kan som påpeget af Hardman et al. (2010) have stor betydning for, hvilke værdier der formidles til atleterne og dermed også for den bredere dannelse, der rækker ud over det rent tekniske og taktiske, men som de anser som en nødvendig integreret del af sportsmiljøer.

Sandra er siden første interview rykket op på U16, hvor hun er en af de faste nøglespillere på førsteholdet. Imidlertid er der kamp om pladserne på holdet. 
På andetholdet er der en anden dygtig spiller, der spiller samme plads som Sandra. Hun oplever, at konkurrencesituationen, og det kompetitive træningsmiljø U16-træneren har skabt, både udvikler og presser hende. Men også på måder der kan karakteriseres som problematiske. Sandra har haft skadesproblemer med sin ryg, fordi hun vokser for hurtigt, men hun spiller og træner alligevel, selvom hun i perioder har store smerter. Det skyldes, at hun er bange for at miste sin position på holdet, hvis hun virker for svag:

Vi er tre spillere på min position. Jeg har været skadet med min ryg, men jeg spiller nogle gange med alligevel. Til løbetræning må jeg sætte mig ud, for det er rigtig hårdt for ryggen. Træneren han siger mange gange, at hende den anden er blevet rigtig god, og at hun bare scorer på alt. Så bliver jeg sådan: Nå, nu skal jeg vist til at tage mig sammen. Så kunne jeg godt lige mærke det. Det gør ret ondt til tider. Jeg taler ikke længere med træneren om det, for jeg vil helst ikke virke klynkende. Prøver bare at være med, men bliver tit nødt til at sætte mig ud. (Sandra - interview 2)

Ud fra gængse praksisser for en forsvarlig talentudvikling (Team Danmark 2017) er det problematisk, at træneren ikke tager hensyn til Sandras skadesproblematik. Imidlertid er det ikke et enestående eksempel på, at vores unge atleter kan være i træningsmiljøer, hvor der er direkte pres på, at de spiller og træner, selvom de har skadesproblemer, fx hvor det er forbundet med vigtige kampe, eller fordi der mangler spillere. Det kan også som hos Sandra ske mere indirekte ved, at konkurrencesituationen og faren for at miste pladsen presser dem til at vise hårdførhed og nådesløst commitment.

I det tredje interview med Sandra har hun ikke længere skadesproblemer, og der er sket den udvikling, at hun har fået lov at spille med førsteholdet på U18-holdet på trods af, at hun kun er førsteårs-U16-spiller. Det oplever hun som et kæmpe cadeau, og det har givet hende ekstra motivation. Ganske interessant kan hun fortælle, at hun "var gået død i håndbolden og den meget træning”, men paradoksalt nok har den ekstra træning og særligt den anerkendelse, hun har făet fra U18-træneren, fået hende til "at ville investere mere i håndbolden". Det har været en stor oplevelse for hende at spille med U18. Hun fortæller, at det kan gøre fysisk ondt at spille mod de bedste U18-spillere, men det har bidraget til at udvikle hendes spil, og hun har nu etableret sig som fast spiller på holdet. I et fremtidsperspektiv er håndbolden det, hun umiddelbart vil prioritere højest. Skiftene i commitmentet til elitesporten ser for Sandras vedkommende ud til at være tæt forbundet med hendes skiftende relationer til trænere og de forskellige muligheder, de giver hende for at udvikle sig og få billeder af sig selv som et større eller mindre talent. Sandras historie og det, vi kan kalde hendes livscyklus med elitesport (Jf. Jowett \& Wylleman 
2006), er interessant ved, at den viser, hvor vigtige relationer kan være for det fortsatte engagement. Hvis Sandra ikke havde fået muligheden af U18-træneren for at spille på U18-holdet og dermed også en ny trænerrelation, var det ikke utænkeligt, at hun ville have stoppet med at spille håndbold på eliteniveau. Det understreger igen betydningen af træneren både som gatekeeper til muligheder og ressourcer og som en relation, der kan bidrage til, at talentfulde atleters store engagement $\mathrm{i}$ sporten giver mening.

\section{DISKUSSION: TRAENERRELATIONEN ER AFGØRENDE FOR TALENTTILBLIVELSEN}

Trænere er bogstaveligt talt nøglepersoner - gatekeepere - i unge atleters tilblivelse som talenter, da de har en central position til at kunne give adgang til deltagelse i talentudviklingsmiljø. Det gælder bl.a. adgangen til idrætsklasserne og det talentudviklingsmiljø, det udgør. Her er trænerne med til at afgøre, om en ung atlet kan påhæftes et prædikat som talent eller ej. Trænerne er også gatekeepere for unge atleters adgang til at træne med de bedste atleter og for udtagelser til kampe og stævne og derved afgørende for, hvilke muligheder udøverne får for at gøre talent. Relationen til trænere er asymmetrisk, da trænere som oftest befinder sig i en magtposition i kraft af den selektion de varetager (Kilger 2017), hvor de kan afgøre, hvorvidt talentet fortsat er til stede, og det fortsat er værd at engagere sig i tilblivelsesprocessen. Derfor kræver varetagelsen af relationen en særlig form for etik af trænerne og et blik for, hvorvidt adgangen til talentudviklingen er fair og retfærdig eller ej (jf. Hardman et al. 2010 og Bailey \& Toms 2011). For når talentet er udvalgt, gives det muligheder, som andre ikke får, og som dermed gør det yderst vanskeligt for de unge udøvere, der ikke kom gennem nåleøjet, at blive til som talenter.

Trænere indgår som den måske mest centrale aktør i distribuering af de ressourcer, der kan hjælpe en ung atlet til at nå eliten. Hvem der er synlige talenter, og hvem der ikke er det, kommer derfor også til at være en selvforstærkende proces. De unge atleter, der anses som talentfulde, får adgang til ressourcer, som styrker deres muligheder for at gøre talent, mens andre udelukkes herfra. Trænerne medvirker ofte aktivt til at synliggøre, producere og reproducere talentet gennem at have en særlig opmærksomhed på, hvad der kan hjælpe netop denne unge atlet frem. Trænerne er derfor mere end gatekeepere, da det ikke kun handler om adgang til et talentmiljø, men også om at give atleten mulighed for at manifestere sig som talent fx gennem fast spilletid, hvilke positioner på banen man får lov at have, om man er den der tager straffespark eller -kast, og om man bærer anførerbindet. At være ressourcedistributør tydeliggør den asymmetriske position træneren har i relation til atleterne. De kan på den ene side fordele ressourcer til de atleterne, de anser som talentfulde, men også trække disse tilbage eller indføre sanktioner, hvis 
de ikke vurderer, at udøverne udviser den fornødne commitment eller udvikler sig på den rette måde og med den rette takt.

Martindale et al. (2007) peger på, at der er behov for at skabe talentudviklingsmiljøer, der både formår at fastholde en større bredde af talentfulde atleter og samtidigt arbejder mere individuelt med de enkelte udøvere. Det er imidlertid et dilemma for talentudviklingsmiljøer at finde den rette balance for, hvordan og til hvem ressourcer og udviklingsmuligheder skal distribueres til. Fx er det spørgsmålet om alle U16-håndboldspillere kan tilbydes muligheder for at træne med U18-truppen for at lette deres overgange i stedet for, at det udelukkende tilbydes de få som et bevis på deres synlige talent?

Vi har med håndboldspilleren Sandra set et eksempel på, at trænere er i en position, hvor de let kan komme til at presse atleter på måder, der ikke udviser den fornødne forsvarlighed over for atleternes langsigtede udvikling og helbred. Det forekommer at være et dilemma i elitesportens talentudvikling, at muligheder og ressourcer distribueres efter atleternes commitment og præstationer, hvorved atleterne kan blive presset til at skulle præstere, selvom kroppen i nogle tilfælde siger fra. Det forekommer ekstra smerteligt for de unge atleter, hvis de i relation til skadesforløb oplever, at miste trænernes engagement i dem. Det kan nærmest beskrives som en dehumanisering (jf. Nussbaum 2010) af de unge atleter, hvis de udelukkende ses som en ressource for talentudviklingen og ikke som hele mennesker. Heldigvis er der også masser af eksempler på, at trænerne har en personlig relation til udøverne, hvor de også udviser interesse i og forståelse for de unge atleters liv uden for sporten. Astrid, der kunne tale med sin træner om vanskeligheder i relation til hendes forældres skilsmisse, er et blandt flere eksempler på en mere helhedsorienteret indstilling til de unge atleters tilblivelse både som talenter og mennesker. Trænere kan således godt blive en vigtig sparringspartner for de unge atleter og deres tilblivelse som talenter, hvis de udviser et engagement i dem som individer. Potentielt åbner det for et mere ligeværdigt og symmetrisk magtforhold i relationen mellem aktørerne. Flere af de unge atleter giver eksempler på, at trænerne opbygger en tæt relation til dem. Trænerne bliver i disse fortællinger vigtige samtalepartnere for deres overvejelser over tilværelsen som talenter, og hvorvidt de kan nå senioreliten, men også for hvordan denne tilblivelse knytter sig til deres øvrige liv. I disse relationer er træneren medvirkende til at skabe mening.

Endeligt kan vi se, at der i talenttilblivelsen somme tider skabes en form for alliance og tæt partnerskab mellem talenter og trænere, da begge parter kan have en interesse i, at talentets tilblivelse og stræben mod senioreliten lykkes. Et forhold der særligt forekommer blandt de unge atleter, der anses som de mest talentfulde. Hvis trænerne formår at udvikle talenter, der kan begå sig i senioreliten, så peger det på, at de er dygtige talentudviklere, hvilket gør det lettere for dem at tiltrække andre talent- og håbefulde unge til talentudviklingsmiljøet. Der kan opstå et 
interessefællesskab mellem atlet og træner om tilblivelsen af talent. Et fællesskab der potentielt kan række ud over det snævre sportslige domæne og muliggøre et fokus på tilblivelsen som helt idrætsmenneske. Omvendt kan den tætte relation mellem atlet og træner medføre, at begge parter kan føle sig ganske svigtet, hvis den anden parts engagement i talenttilblivelsen ophører. Derfor kan det være særdeles svært for talenter at fortælle deres trænere, hvis de ikke længere ønsker at investere tid og engagement i eliteidrætten, eller atleter kan blive ganske skuffede, hvis trænere ikke længere investerer samme engagement i dem og måske ligefrem ophører med at distribuere ressourcer og udviklingsmuligheder til dem.

\section{KONKLUSION}

Idræt er en social affære, og tilblivelsen som talent er et relationelt forhold. Både forskningslitteraturen og vores undersøgelse viser, at unge atleters relationer til trænere spiller en betydningsfuld rolle i det, vi har betegnet som en tilblivelsesproces. Imidlertid er det ikke altid en relation, der positivt forbinder sig til unge atleters udvikling mod eliten, og som de oplever som værende meningsfuld.

Trænere har en position, hvor de kan opstille forhindringer for atleter og deres adgang til og deltagelse i talentudviklingsmiljø, der kan medvirke til, at atleters tilblivelse som talenter vanskeliggøres eller ligefrem ophører. Trænere er nøglepersoner, der kan åbne op for muligheder og skabe drømme hos unge atleter, men de har også en position, der gør dem i stand til det modsatte - at lukke muligheder for unge og potentielt briste deres drømme. Vi tilslutter os derfor den forståelse, at det er vigtigt at have blik for livscyklussen af relationer mellem trænere og atleter, hvor man både undersøger, hvordan relationerne initieres, vedligeholdes og opløses (Jowett \& Wylleman 2006). Vi har givet eksempler på unge atleter, der oplever, at trænere engagerer sig i dem, er med til at tænde deres glød og distribuere muligheder til dem for at gøre talent, men vi har også vist eksempler på det modsatte, hvor unge atleter beretter om trænere, der ikke (længere) udviser engagement i dem, som ikke giver dem adgang til kunne gøre talent og derved bidrager til at slukke deres glød.

Med vores blik på talenter in the making, hvor vi ikke kun får indblik i talentudviklingsmiljøernes succeshistorier, får vi vist, at trænerens nøgleposition i talentudviklingen også indebærer et etisk ansvar for dem, der ikke kommer gennem gaten, får ressourcer distribueret eller opnår et partnerskab. 


\section{REFERENCER}

Bailey, R. \& Toms, M. (2011). Coaching and ethics of youth talent identification: rethinking luck and justice. In A. R. Hardman \& C. Jones (Eds.), The ethics of sports coaching. (pp. 149-164). Routledge.

Becker, A. J. (2009). It's Not What They Do, It's How They Do It: Athlete Experiences of Great Coaching. International Journal of Sports Science \& Coaching, Vol 4, No. 1(9), 93-119. https://doi.org/10.1260/1747-9541.4.1.93

Epstein, D. (2014). The sports gene: Inside the science of extraordinary athletic performance. New York: Current.

Fox, N. \& Alldred, P. (2017). Sociology and the New Materialism. Theory, Research, Action. London: Sage.

Hardman, A., Jones, C. \& Jones, R. (2010). Sports coaching, virtue ethics and emulation. Physical Education and Sports Pedagogy, Vol. 15, No. 4, 345-359. https://doi. org/10.1080/17408980903535784

Henriksen, K. (2010). The Ecology of Talent Development in Sport: A Multiple Case Study of Successful Athletic Talent Development Environments in Scandinavia, Doctoral Thesis. Odense: University of Southern Denmark.

Henriksen, K., Stambulova, N. \& Roessler, K. K. (2010). Holistic approach to athletic talent development environments: A successful sailing milieu. Psychology of Sport and Exercise, 11 (3), 212-222. http://dx.doi.org/10.1016/j.psychsport.2009.10.005

Højgaard, L. \& Søndergaard, D. M. (2010). Multimodale konstitueringsprocesser i empirisk forskning. In S. Brinkmann \& L. Tanggard (Eds.), Kvalitative metoder. København: Hans Reitzels Forlag.

Jowett, S. \& Wylleman, P. (2006). Editorial: Interpersonal relationships in sport and exercise settings: Crossing the chasm. Psychology of Sport and Exercise, 2006(7), 119-123. Elsevier.

Karen, D. \& Washington, R. E. (2015). Sociological Perspectives on Sport. The Games Outside the Games. London \& New York: Routledge.

Kilger, M. (2017). Talking talent. Narratives of youths sports selection. Stockholm: Stockholm University.

Kilger, M. \& Jonsson, R. (2015). Talent Production in Interaction: Performance Appraisal Interviews in Talent Selection Camps. Communication \& Sport. June 28, 2015, 1-20. Sage.

Krogh Christensen, M. (2009). "An Eye for Talent”: Talent Identification and the "Practical Sense” of Top-Level Soccer Coaches. Sociology of Sport Journal, Vol. 26(3), 365-382.

Larsen, C.H., Alfermann, D., Henriksen, K. \& Christensen, M.K. (2013). Successful Talent Development in Soccer: The Characteristics of the Environment. Sport, Exercise and Performance Psychology, 13, 2, 190-206. http://dx.doi.org/10.1037/aoo31958 
Martindale, R. J., Collins, D. \& Abraham, A. (2007). Effective Talent Development: The Elite Coach Perspective in UK Sport". Journal of Applied Sport Psychology, 19(2), 187206. Routledge. https://doi.org/10.1080/10413200701188944

Mialet, H (2006). Do Angels Have Bodies: Two Stories About Subjectivity in Science, The Cases of William X and Mr. H. In E. Selinger \& R. P. Crease (Eds.), The Philosophy of Expertise (pp. 332-346). New York: Columbia University Press, 246-279.

Mialet, H. (2009). Making a Difference by Becoming the Same. International Journal of Entrepreneurship and Innovation. 10/4, 09, 257-265.

Mol, A. \& Law, J. (2004): Embodied Action, Enacted Bodies: The example of Hypoglycemia. Body \& Society, 10(2-3), London: Sage, 43-62.

Nielsen, J. C. \& Olesen, J. S. (Eds.) (2019): Talentudvikling og elitesport i skolen. Århus: Aarhus Universitetsforlag.

Nielsen, J. C., Olesen, J. S. \& Skrubbeltrang, L. S. (2017). Idrætselevernes tilblivelse og transitioner - Idrætsklasser som ny standard for tidlig talentudvikling i Danmark. Aarhus Universitet.

Nussbaum, M. C. (2010). Not for Profit. Why Democray Needs the Humanities. Princeton and Oxford: Princeton University Press.

Ronglan, L. T. (2015). Elite sport in Scandinavian welfare states: Legitimacy under pressure?. International Journal of Sport, Policy and Politics, 7(3), 345-363. https://doi.or $\mathrm{g} / 10.1080 / 19406940.2014 .987309$

Russell, J., Martindale, R., Collins, D. \& Daubney, J. (2013). Talent development: A guide for practice and research within sport. Quest, 7 (4), 353-375. https://doi.org/10.1080/o 0336297.2005.10491862

Skrubbeltrang, L. S., Olesen, J. S. \& Nielsen, J. C. (2015). How to stay becoming - living up to the code of conduct in a sports class. Ethnography and Education, 11(3), 371-387. https://doi.org/10.1080/17457823.2015.1109467

Stambulova, N. B., Engström, C., Franck, A., Linnér, L., \& Lindahl, K. (2015). Searching for an optimal balance: Dual career experiences of Swedish adolescent athletes. Psychology of Sport \& Exercise, 21, 4-14. http://dx.doi.org/10.1016/j.psychsport.2014.08.009

Storm, L. K., Henriksen, K., Larsen, C. H. \& Christensen, M. K. (2014). Influential Relationships as Contexts of Learning and Becoming Elite - Athletes' Retrospective Interpretations. International Journal of Sports Science \& Coaching, Vol. 9, No. 6, 1341-1356. https://doi.org/10.1260/1747-9541.9.6.1341

Team Danmark (2017). ATK 2.o Træning af børn og unge. Team Danmark. Lokaliseret 8.6.2017: https://umbraco.teamdanmark.dk/media/1667/atk-20_low.pdf

Wylleman, P., Alfermann, D., \& Lavellee, D. (2004). Career transitions in sport. European perspectives. Psychology of Sport and Exercise, 2004, 5, 7-20. Elsevier. https://doi. org/10.1016/S1469-0292(02)oo049-3 
Wylleman, P. \& Lavellee, D. (2004). A developmental perspective on transition faced by athletes. In M. Weiss (Ed.), Developmental sport and exercise psychology (pp. 507-527). Morgantown: WV: Fitness Information Technology.

Fotos: Colourbox.dk

\section{Abstract DK}

Artiklen belyser relationer mellem unge talentfulde atleter og deres trænere. Ved at læse på tværs af interviewmateriale med unge idrætstalenter finder vi tre former for nøglerelationer trænere kan have i talentudviklingen, henholdsvis som gatekeepere, ressourcedistributører og partnere. Analyserne viser, at trænere indtager en nøgleposition i talentudvikling og talentudviklingsmiljøer, hvor de har en central betydning for tilblivelsen af unge talenter. Det diskuteres om den nøgleposition i talentudviklingen også indebærer et etisk ansvar for dem, der ikke kommer gennem gaten, får ressourcer distribueret eller opnår et partnerskab.

\section{Abstract UK}

The aim of the article is to study talent as a relational phenomenon. Based on analysis of how young athletes and coaches affect each other, the article discuss the ethical questions brought forward by the focus on the dynamic relationships and the power relations in talent development.

The study points to three different types of key relationships coaches hold in talent development, respectively being gatekeepers, resource distributors and partners. The analysis shows that coaches have a position in which they can both promote and inhibit access to and participation in talent development environments and their resources.

\section{Forfatterinfo:}

Jens Christian Nielsen, ph.d., lektor, DPU - Aarhus Universitet, jcn@edu.au.dk Kontaktperson (corresponding author) - kontaktdata:

DPU, Aarhus Universitet (Campus Emdrup)

Tuborgvej 164, København NV

Tel: (+45) 29426724 - Email: jcn@edu.au.dk

Lotte Stausgaard Skrubbeltrang, ph.d., studielektor, Institut for Medicin og Sundhedsteknologi, Aalborg Universitet lss@hst.aau.dk

Jesper Stilling Olesen, ph.d., lektor, DPU - Aarhus Universitet, jeo@edu.au.dk 